\title{
ZABURZENIA ODŻYWIANIA WŚRÓD UCZNIÓW SZKÓt CIESZYŃSKICH
}

\author{
NUTRITIONAL DISORDERS AMONG CIESZYN HIGH SCHOOL STUDENTS
}

\author{
Dariusz Góra \\ Wydział Nauk o Ziemi, Uniwersytet Śląski \\ DOI: https://doi.org/10.20883/ppnoz.2019.28
}

STRESZCZENIE

Wstęp. Obecnie młodzież oraz dzieci popełniają liczne błędy żywieniowe. Należą do nich: nadmierne spożywanie pokarmów, wzrost spożycia słodkich napojów, częste i obfite posiłki, łatwość zakupu żywności gotowej do spożycia typu fast food o dużej zawartości tłuszczu, ograniczenie spożycia warzyw i owoców oraz wzrost konsumpcji słodyczy. W Polsce nadwaga i otyłość dotyczy ponad 12\% dzieci i młodzieży w wieku szkolnym.

Cel pracy. Celem artykułu jest poznanie i omówienie form spędzania wolnego czasu, uczestnictwa w zajęciach z wychowania fizycznego i sposoby żywienia się uczniów w szkołach ponadgimnazjalnych na terenie Cieszyna.

Materiał i metody. Materiał badawczy został zebrany w styczniu 2018 r. Do pracy użyto autorskiego kwestionariusza pod tytułem „Moje zdrowie - dbam o nie". Anonimowa ankieta zawierała kilka pytań dotyczących sposobu żywienia, formy spędzania wolnego czasu oraz uczestnictwa w zajęciach z wychowania fizycznego w szkole. Ankieta była skierowana do uczniów klas III szkół średnich (189 chłopców i 178 dziewcząt). Obliczenia (z podziałem na płeć) ujęto w tabelach i dokonano ich interpretacji.

Wyniki. Oglądanie telewizji deklaruje 37\% chłopców i 32\% dziewcząt. Jest to najczęstsza forma spędzania wolnego czasu. W zajęciach z wychowania fizycznego regularnie uczestniczy $72 \%$ ankietowanych chłopców i 61\% dziewcząt. Aż 46\% ankietowanych chłopców i 42\% dziewcząt przyznało się do konsumpcji słodyczy co najmniej 5 razy w tygodniu, a fast foody co najmniej raz w tygodniu przez 24\% chłopców i 21\% dziewcząt.

Wnioski. Badania wykazały istnienie szeregu nieprawidłowości w sposobie odżywiania się młodzieży. Powszechnie panujące przekonanie, że szzzupła sylwetka jest atutem w dzisiejszych czasach skłania wiele osób do korzystania z wielu diet odchudzających lub głodówek, które nadmiernie stosowane mogą stanowić zagrożenie dla rozwijającego się organizmu. Respondenci wykazują również niedostateczną aktywność fizyczną.

172 Słowa kluczowe: młodzież, nawyki żywieniowe, aktywność fizyczna.

ABSTRACT

Introduction. Currently, adolescents and children commits numerous nutritional errors. These include: excessive consumption of food, increased consumption of sweet drinks, frequent and hearty meals, easy purchase of ready-to-eat food fast food with a high fat content, limitation of vegetable and fruit intake, and increased consumption of sweets. In Poland, overweight and obesity affect over 12\% of children and youth in school age.

Aim. The aim of the article is to present the diet of high school students in Cieszyn.

Material and methods. The research material was collected in January 2018. The author's questionnaire entitled "My health - I care for him" was used for the work. An anonymous questionnaire contained several questions about diet, forms of spending free time and participation in physical education classes at school. The questionnaire was targeted at third grade high school students (189 boys and 178 girls). Based on the calculations made (broken down by gender), appropriate tables were made and interpreted.

Results. $37 \%$ of boys and $32 \%$ of girls declare to watch television. This is the most common form of spending free time. $72 \%$ of boys surveyed and $61 \%$ of girls regularly participate in physical education classes. As many as $46 \%$ of the boys surveyed and $42 \%$ of girls admitted that they consume sweets at least 5 times a week and fast food at least once a week by $24 \%$ boys and $21 \%$ girls.

Conclusions. Research has shown the existence of a number of irregularities in the way of feeding young people. The widely-held belief that slim figure is an advantage nowadays induces many people to use many weight loss diets or starvation diets, which excessive use can pose a threat to the developing organism. Respondents also show insufficient physical activity.

Keywords: adolescents, eating habits, physical activity.

\section{Wstęp}

Obecnie młodzież oraz dzieci popełniają liczne błędy żywieniowe. Należą do nich: nadmierne spożywanie pokarmów, wzrost spożycia słodkich napojów, częste i obfite posiłki, łatwość zakupu żywności gotowej do spożycia typu fast food o dużej zawartości tłuszczu, ograniczenie spożycia warzyw i owoców oraz wzrost konsumpcji słodyczy. Konsekwencję niewłaściwej diety i małej aktywności fizycznej stanowi narastający problem otyłości już we wczesnymokresieżycia. W Polscenadwagai otyłość dotyczy ponad 12\% dzieci i młodzieży w wieku szkolnym. Poznanie stylu życia młodych ludzi i próby modyfikacji niewłaściwych elementów mogą przyczynić się do ograniczenia tego problemu.

Zdrowie, według Światowej Organizacji Zdrowia (WHO), to nie tylko brak choroby, ale stan pełnego, dobrego samopoczucia fizycznego, psychicznego i społecz- 
nego. Podkreśla się $w$ nim aspekt wielowymiarowości i subiektywny charakter zdrowia. Ważną rolę w procesie kształtowania i ochrony zdrowia odgrywa styl życia człowieka, a przede wszystkim nawykowy wzorzec postępowania wobec własnego ciała. Może on przybierać formę zachowań służących utrzymaniu lub przywróceniu zdrowia oraz zachowań powodujących bezpośrednie lub odległe szkody zdrowotne. Zachowania zdrowotne można podzielić na sprzyjające zdrowiu (prozdrowotne, pozytywne) oraz antyzdrowotne (negatywne, autodestrukcyjne). Zachowania prozdrowotne służą wspieraniu zdrowia, zapobieganiu chorobie oraz wspomaganiu powrotu do zdrowia. Natomiast zachowania antyzdrowotne przyczyniają się do powstania zaburzeń stanu zdrowia, negatywnych oddziaływań w sferze emocjonalnej, fizycznej i psychicznej [1].

Istotne znaczenie z perspektywy stosowania mechanizmów wpływu społecznego ma poziom świadomości własnych zachowań zdrowotnych. To właśnie od poziomu świadomości jednostki zależy kształtowanie zachowań pro lub antyzdrowotnych. Na kształtowanie się zachowań zdrowotnych wpływ ma wiele czynników leżących zarówno po stronie jednostki, jak i otoczenia.

Modelowanie zachowań przez rodziców i opiekunów we wczesnym okresie życia dziecka skutkuje wykształceniem się określonych nawyków. Proces ten jest następnie wzmacniany lub modyfikowany w ramach dalszej socjalizacji zachodzącej w środowisku przedszkolnym, potem szkolnym i rówieśniczym a w późniejszych latach także w środowisku zawodowym i towarzyskim. Modelowanie zachowań odnosi się do zdrowia i jego aspektów: jakość odżywiania się, aktywności fizycznej i profilaktyki zdrowotnej.

Zachowania zdrowotne są wyznaczone również przez tzw. kontekstem społecznym i zdrowotnym. Kultura kształtuje m.in. ogólny poziom życia członków danej zbiorowości, wyobrażenia o zdrowiu i chorobie, sposób spostrzegania, odczuwania, opisywania i interpretowania objawów chorobowych, stan wiedzy na temat przyczynowości chorób, postawy i zachowania wobec własnej choroby a także stylu życia danej zbiorowości.

Nie bez znaczenia w kształtowaniu zachowań zdrowotnych są różnego rodzaju media. Intensywny rozwój techniki spowodował, że media stały się ważnym źródłem informacji, w tym także o zdrowiu. Upowszechnieniu wiedzy na temat zdrowia ichoroby służą także różne kampanie społeczne. Wśród kampanii i ruchów społecznych można wyróżnić te, które sprzyjają zachowaniom prozdrowotnym oraz takie, które wpływać mogą na zdrowie negatywnie (np. różnego rodzaju strony internetowe promujące głodzenie się, argumentacja przeciw szczepieniu dzieci itp.).
Jednym z zachowań prozdrowotnych jest aktywność fizyczna. Podstawowym czynnikiem budującym świadomość jest edukacja w zakresie rekreacji ruchowej. Lekcje wychowania fizycznego w szkole i ruchowe zajęcia pozalekcyjne są optymalnym miejscem do dostarczania dzieciom i młodzieży potrzebnej dawki ruchu. Istotną rolę pełnią jednak zajęcia wychowania fizycznego, które mają jeszcze za zadanie usamodzielnienie młodej osoby w zakresie rekreacji ruchowej. Systematyczne czynności ruchowe dzieci i młodzieży są bodźcem do wielu korzystnych zmian zachodzących w ich organizmie. Należy do nich poprawienie sylwetki własnego ciała, wzrost masy mięśniowej, sprężysty chód, zwiększona odporność na zmęczenie przy pracy fizycznej, lepsze samopoczucie a organizm staje się silniejszy, szybszy i bardziej wytrzymały. Minimum aktywności ruchowej u dziecka badacze wytyczają na 6 godzin zorganizowanego ruchu $w$ tygodniu. Największą potrzebę ruchową dzieci wykazują w wieku przedszkolnym i wczesnoszkolnym. Jest ona bowiem korzystna dla prawidłowego rozwoju umysłowego i fizycznego dziecka. Niespełnienie minimalnej normy aktywności ruchowej przyczynia się do ograniczenia wszelakich procesów zachodzących w okresie rozwoju dziecka oraz może się stać czynnikiem hamującym rozwój świadomości i aktywności ruchowej w dalszych etapach życia [1, 2].

Celem artykułu jest próba przedstawienia sposobu odżywiania się uczniów szkół ponadgimnazjalnych na terenie Cieszyna.

\section{Materiał i metody}

Materiał badawczy został zebrany w styczniu 2018 r. Do pracy użyto autorskiego kwestionariusza pod tytułem "Moje zdrowie - dbam o nie". Anonimowa ankieta zawierała kilka pytań dotyczących sposobu żywienia, formy spędzania wolnego czasu oraz uczestnictwa w zajęciach z wychowania fizycznego w szkole. Ankieta była skierowana do uczniów klas III szkół średnich (189 chłopców i 178 dziewcząt). Na podstawie dokonanych obliczeń (z podziałem na płeć) dokonano odpowiednie tabele i dokonano ich interpretacji.

Ankieta zawierała następujące pytania:

1. Podaj najczęstszą formę spędzania przez ciebie wolnego czasu.

2. Czy regularnie uczestniczysz w szkole w lekcjach z wychowania fizycznego?

3. Podaj częstość spożywania przez ciebie określonego rodzaju żywności.

4. Wymień najczęściej wypijany przez ciebie napój.

5. Podaj produkt spożywczy, który najczęściej spożywasz mieli na drugie śniadanie. 


\section{Wyniki}

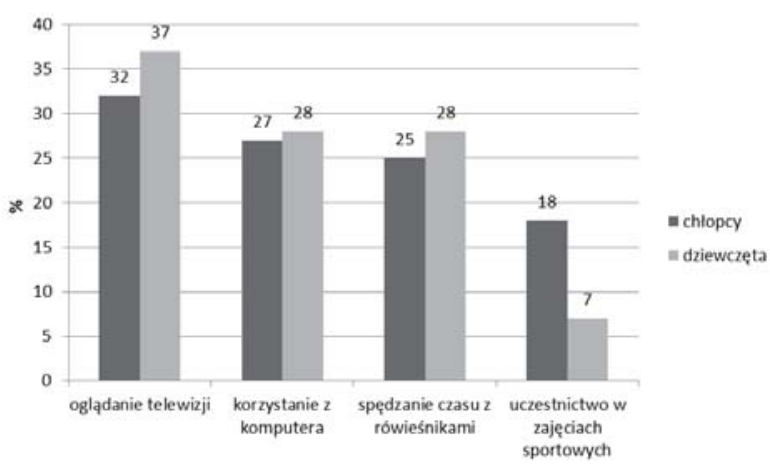

Rycina 1. Forma spędzania wolnego czasu (opracowano na podstawie zebranych danych)

Oglądanie telewizji to najczęstsza forma spędzania wolnego czasu (37\% chłopców i 32\% dziewcząt). Natomiast korzystanie z komputera jako spędzanie czasu wolnego zadeklarowało $27 \%$ ankietowanych chłopców i $28 \%$ dziewcząt. 28\% badanych dziewcząt i 25\% chłopców spędza czas wolny z rówieśnikami. Tylko 7\% dziewcząt i 18\% chłopców wybrało uczestnictwo w zajęciach sportowych jako formę spędzania wolnego czasu (Rycina 1).

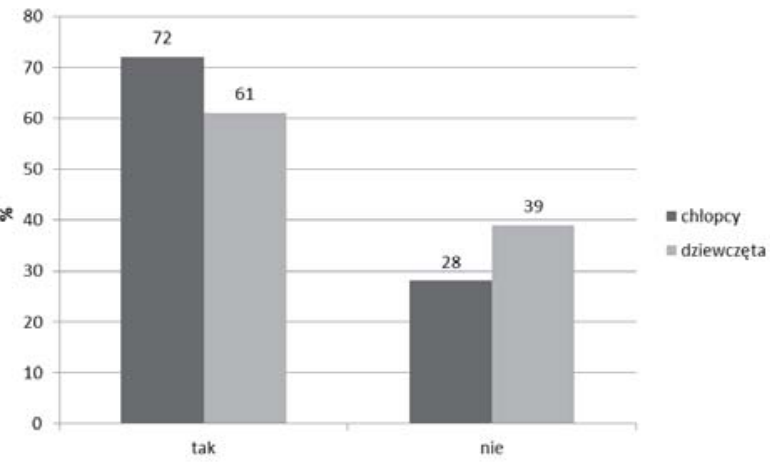

Rycina 2. Uczestnictwo w zajęciach wychowania fizycznego (opracowano na podstawie zebranych danych)

Regularnie uczestniczy $72 \%$ ankietowanych chłopców i $61 \%$ dziewcząt w zajęciach wychowania fizycznego. 28\% chłopców i aż 31\% dziewcząt przyznało, że nie uczestniczy w zajęciach z wychowania fizycznego. Z przeprowadzonych badań wynika również, że aż 75\% (chłopców i dziewcząt) ankietowanych odpowiedziało, że główną przyczyną braku aktywności fizycznej jest brak chęci oraz wygląd swojego ciała (Rycina 2).

Aż 46\% ankietowanych chłopców i 42\% dziewcząt przyznało się, że słodycze są przez nich konsumowane co najmniej 5 razy $w$ tygodniu, a fast foody co najmniej raz w tygodniu przez 24\% chłopców i 21\% dziewcząt. Poza tym zaobserwowano na podstawie ankiet związek pomiędzy preferowanym positkiem a płcią badanych. Dziewczęta czę- ściej wybierały warzywa i owoce (21\%) niż chłopcy (8\%), natomiast 22\% chłopców wybiera dania mięsne w przeciwieństwie do $16 \%$ ankietowanych dziewcząt (Rycina 3).

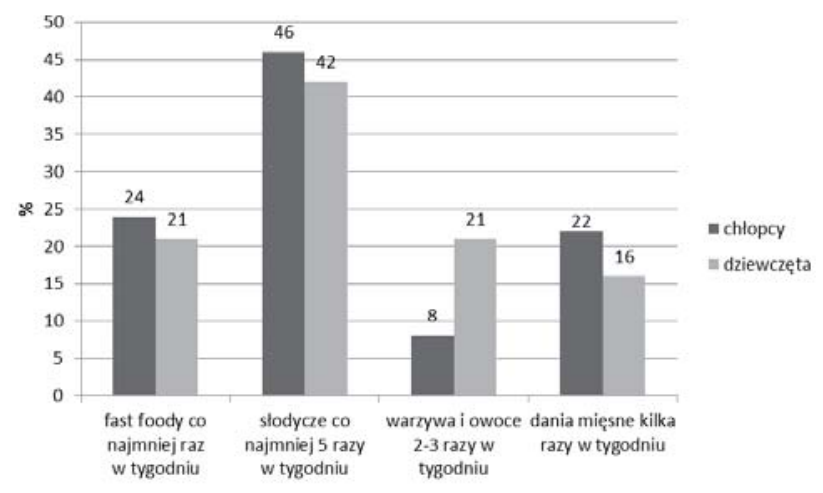

Rycina 3. Częstość spożywania określonego rodzaju żywności (opracowano na podstawie zebranych danych)

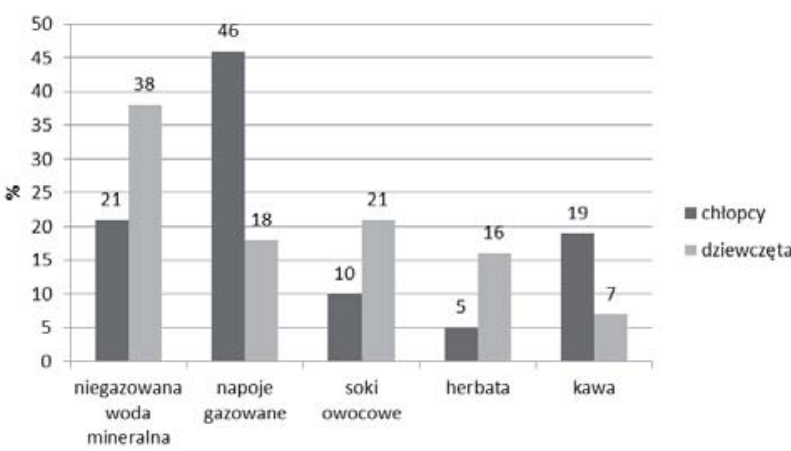

Rycina 4. Najczęściej wypijany przez uczniów napój (opracowano na podstawie zebranych danych)

Rodzaj spożywanych przez uczniów napojów był istotnie zależny od ich płci. Dziewczęta preferowały niegazowana wodę mineralną (38\%) i soki owocowe (21\%) w przeciwieństwie do chłopców. Najczęściej wybieranym napojem przez chłopców są napoje gazowane (46\%). 19\% ankietowanych chłopców i 7\% dziewcząt przyznaje, że preferowanym przez nich rodzajem spożywanego napoju jest kawa (Rycina 4).

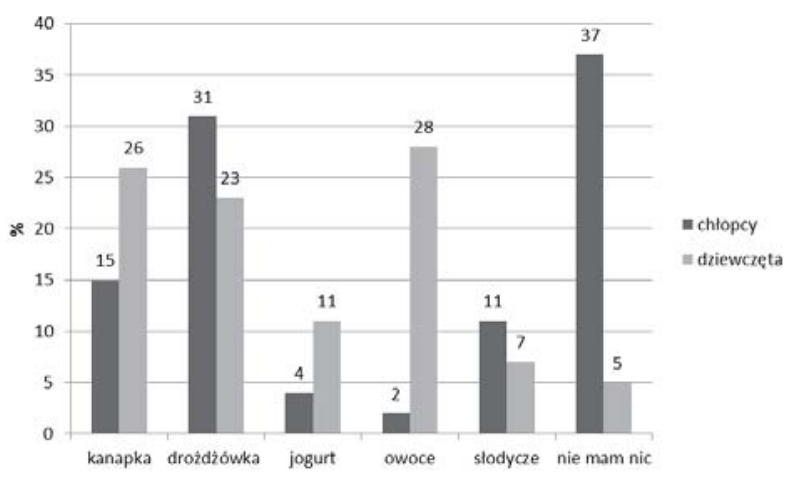

Rycina 5. Produkt spożywczy, który uczniowie najczęściej mieli ze sobą na drugie śniadanie (opracowano na podstawie zebranych danych) 
Aż 37\% ankietowanych chłopców nie spożywa drugiego śniadania na terenie szkoły. Drożdżówka wybierana jest przez 31\% chłopców i 23\% dziewcząt. Owoce deklaruje $28 \%$ badanych dziewcząt i tylko 2\% chłopców. Jogurt jako drugie śniadanie preferuje $11 \%$ dziewcząt i 4\% chłopców, a kanapkę 26\% dziewcząt i tylko 15\% chłopców (Rycina 5).

\section{Dyskusja}

Mała aktywność fizyczna w dzisiejszych czasach jest dużym zagrożeniem dla zdrowia dziecka. Jedną z najczęstszych chorób wśród dzieci i młodzieży są zaburzenia ruchu, w tym wady postawy. Niestety, inne wady również dają niepokojący wizerunek obecnej sytuacji zdrowotnej dzieci, tzn. problemy z kręgosłupem czy też wada wzroku. Szczególną tendencją zaś odznaczają się zaburzenia dotyczące wagi zwłaszcza nadwaga i otyłość. Można temu zapobiec m.in. przez systematyczną aktywność fizyczną, w przeciwnym razie istnieje możliwość wystąpienia również innych chorób związanych z zaburzeniami zdrowia dziecka. Należą do nich choroby układu kostnego, takich jak osteoporoza. Przyczyną jej występowania jest niedostateczne obciążenie układu kostnego. Organizm bez długotrwałej aktywności fizycznej traci gęstość tkanki kostnej i następuje wyraźna utrata wapnia i fosforu oraz zwiększony rozpad tkanki kostnej. Jedynie zwiększona aktywność ruchowa ma duże znaczenie dla zmniejszenia wystąpienia osteoporozy [3].

Kolejną chorobą, która może zagrozić zdrowiu dziecka spowodowaną brakiem aktywności fizycznej jest choroba niedokrwienna serca. Do jej wystąpienia prowadzi miażdżyca tętnic wieńcowych, czyli odkładanie się substancji tłuszczowych na wewnętrznych ścianach tętnic. Zmniejszona aktywność fizyczna powoduje mniejsze występowanie krążącej krwi, przez co zmniejsza się liczba występowania erytrocytów. W następstwie pociąga to za sobą niedotlenienie organizmu, co $w$ konsekwencji prowadzi do zmniejszenia wydolności fizycznej i upośledzenia organizmu. Pozostanie przez dłuższy czas bez aktywności ruchowej może doprowadzić do otyłości $[3,4]$.

Polskie społeczeństwo zaliczane jest w Europie do mało aktywnych ruchowo, zwłaszcza w zakresie zorganizowanej aktywności sportowej. Wraz z wiekiem wzrasta liczba osób preferujących bierne, statyczne formy wypoczynku. Z przeprowadzonych licznych badań wynika, że również dzieci i młodzież coraz częściej wykazują się niską aktywnością fizyczną i biernym sposobem spędzania wolnego czasu. Uczniowie spędzają więcej czasu przed telewizorem bądź przy komputerze i unikają zajęć sportowych.
Na podstawie badań ankietowych przeprowadzonych na terenie Cieszyna również wynika, że młodzież szkół ponadgimnazjalnych niechętnie uczestniczy w zajęciach wychowania fizycznego w szkole. Przyznaje się do tego $28 \%$ chłopców i aż 39\% dziewcząt. Tylko 7\% dziewcząt i 18\% chłopców aktywność sportową uważa za formę spędzania wolnego czasu (Ryciny 1 i 2).

Otyłość to stan patologicznego zwiększenia ilości tkanki tłuszczowej jako składowej całości organizmu. Następuje wówczas uszkodzenie czynności i struktury poszczególnych narządów i układów, które zwiększają ryzyko skrócenia średniego oczekiwanego okresu życia. To choroba, która nawet wtedy, kiedy organizm o zwiększonej ilości tkanki tłuszczowej nie wykazuje objawów patologicznych, zagraża w miarę przedłużania się jej trwania rozwojem uszkodzeń narządowych i ogólnych w przyszłości $[5,6]$.

W rzeczywistości nadwaga i otyłość wiążą się z wieloma poważnymi konsekwencjami zdrowotnymi dla dziecka, a później także otyłego dorosłego. Warto zaznaczyć, że konsekwencje te nie wiążą się tylko i wyłącznie z fizycznym funkcjonowaniem, ale również mogą dotyczyć zdrowia psychicznego i społecznego młodego człowieka. Otyłość jako jedno z najczęściej występujących zaburzeń rozwoju dzieci i młodzieży wpływa na wszystkie elementy zdrowia (fizyczne, psychiczne i społeczne) młodego, a następnie dorosłego człowieka, ogranicza jego potencjał rozwojowy, możliwości życiowe i jakość życia [7]

Agresywny marketing i reklamy powodują, że współczesny człowiek spożywa zbyt wiele produktów zawierających dużą zawartość tłuszczów i łatwo przyswajalnych węglowodanów prostych (głównie słodycze) oraz mało wartościowych pod względem odżywczym, a wysoko kalorycznych potraw podawanych w barach szybkiej obsługi (fast foody). Popularne na całym świecie napoje (cola, piwo, lemoniady i inne słodzone napoje) stanowią kolejne, często niedostrzegane przez konsumenta niebezpieczeństwo pochłonięcia dodatkowych kilokalorii.

Zbyt małe spożycie produktów niskokalorycznych obfitujących w błonnik (owoce i warzywa), witaminy i wiele substancji mineralnych stanowi kolejny błąd żywieniowy. Ulubione produkty (hamburgery, frytki, chipsy, słodycze) są wysokokaloryczne i nie zapewniają wystarczającej podaży tych najważniejszych składników $[7,8]$.

Badana młodzież z Cieszyna również wykazała liczne niewłaściwe błędy żywieniowe: brak drugiego śniadania (37\% chłopców), 46\% chłopców jada słodycze co najmniej 5 razy w tygodniu, 24\% chłopców i 21\% dziewcząt je fast foody co najmniej raz $w$ tygodniu (Ryciny $3 \mathrm{i} 4$ ). 
Otyłość to uznana przez Światową Organizację Zdrowia epidemia XXI wieku [9]. Dane epidemiologiczne wskazuja, że w 2015 roku na całym świecie 2,3 mld miało zaawansowaną nadwagę, a $704 \mathrm{mln}$ miało otyłość W Europie około $20 \%$ dzieci do 14 . Roku życia ma nadmiar masy ciała, a u 5\% stwierdza się otyłość. W Polsce problem nadmiernej masy ciała wśród dzieci w wieku szkolnym dotyczy około $18 \%[9,10]$. Problem nadmiaru masy ciała w Polsce dotyczy 10\% dziewcząt i 14\% chłopców w wieku wczesnoszkolnym (7-9 lat). W grupie 13-15-letniej polskiej młodzieży otyłość występuje u 4,5\% badanych, częściej u dziewcząt niż u chłopców a nadwaga u 9\% młodzieży [Wójciak 2009]. W 2010 roku według badań HBSC (Health Behaviour in School-aged Children) odsetki polskich nastolatków z nadmiarem masy ciała należały do największych w Europie. Niemal co czwarty 11-latek, co piąty 13-latek i co siódmy 15 -latek miał nadmiar masy ciała, a w latach 20022010 systematycznie zwiększał się odsetek młodzieży z nadwagą i otyłością [11].

Według Światowej Organizacji Zdrowia zwiększona masa ciała odpowiada za więcej niż milion zgonów rocznie w Europie. Jest również szóstym co do ważności czynnikiem ryzyka odpowiedzialnym za liczbę zgonów na świecie [10].

W ostatnim 25-leciu częstotliwość występowania otytości w Europie wzrosła trzykrotnie. W krajach europejskich wśród dzieci nadwagę i otyłość stwierdzono u ponad 30\% dziewcząt i u 20\% chłopców w przedziale wiekowym 6-10 lat [8].

Za występowanie otyłości i nadwagi odpowiedzialne są w około $25-45 \%$ predyspozycje genetyczne. Wśród pozostałych czynników wyróżnia się złe nawyki żywieniowe, podjadanie między posiłkami, siedzący tryb życia, brak aktywności fizycznej, zaburzenia hormonalne i neurologiczne, krótki czas snu, marketing i reklama [8].

Do typowych konsekwencji zdrowotnych nadwagi i otyłości u dzieci i młodzieży należy: cukrzyca, wysoki poziom cholesterolu, nadciśnienie tętnicze, miażdżyca, niewydolność serca, stłuszczenie wątroby, kamica żółciowa, astma oskrzelowa, zespół bezdechu śródsennego, powikłania ortopedyczne, zmniejszona wydolność fizyczna, zaburzenia koncentracji uwagi [9].

Leczenie otyłości jest procesem trudnym, często mało skutecznym i frustrującym dla dziecka, rodziców oraz lekarza. Jego skuteczność zależy od czynników społeczno-ekonomicznych, kulturowych, emocjonalnych i motywacyjnych. W leczeniu otyłości z założenia nie stosuje się środków farmakologicznych ani chirurgicznie. Proces ten oparty jest na leczeniu dietetycznym, zwiększeniu aktywności fizycznej oraz terapii behawioralnej. Zmiany żywieniowe polegają na wprowadzeniu prawidłowo zbilansowanej diety ubogo energetycznej, normo białkowej o zmniejszonym udziale tłuszczów i węglowodanów. Należy zmniejszyć porcję spożywanych posiłków, unikania podjadania między posiłkami słodyczy i słonych przekąsek, a także ograniczenie spożywania potraw smażonych, bogatych w sól, cukier i tłuszcz [7].

Istotne znaczenie w profilaktyce nadwagi i otyłości wśród dzieci i młodzieży szkolnej ma edukacja zdrowotna [11].

\section{Wnioski}

Badania wykazały istnienie szeregu nieprawidłowości w sposobie odżywiania się młodzieży. Powszechnie panujące przekonanie, że szczupła sylwetka jest atutem w dzisiejszych czasach skłania wiele osób do korzystania z wielu diet odchudzających lub głodówek, które nadmiernie stosowane mogą stanowić zagrożenie dla rozwijającego się organizmu. Respondenci wykazują również niedostateczną aktywność fizyczną.

Uczniowie coraz częściej wybierają bierny wypoczynek, gdyż aktywność ruchowa nie daje im takiej satysfakcj jak chociażby gra na komputerze. Konieczna jest tu głównie współpraca rodziców z dziećmi, gdyż to właśnie od nich $w$ dużej mierze zależy, jak spędzają i będą spędzać wolny czas w przyszłości.

\section{Oświadczenia}

Oświadczenie dotyczące konfliktu interesów

Autorzy deklarują brak konfliktu interesów.

\section{Źródła finansowania}

Autorzy deklarują brak źródeł finansowania.

\section{Piśmiennictwo}

1. Ponczek D, Olszowy I. Styl życia młodzieży i jego wpływ na zdrowie. Probl Hig Epidemiol. 2012;93(2):260-268.

2. Grzywacz R. Rola rekreacji ruchowej w wychowywaniu dzieci w wieku szkolnym. Med Rodz. 2011;2:48-53.

3. Pietrzykowska M, Nowicka-Sauer K, Cwaliński T, Kozińska A Krzemiński W, Obara-Gołębiowska M, Siebert J. Występowanie zaburzeń psychicznych wśród dzieci z otyłością. Family Medicine \&Primary Care Review. 2014;16(2):146-147.

4. Jonczyk P, Potempa M, Kajdaniuk D. Analiza stopnia odżywienia i zaburzeń odżywiania oraz charakterystyka przyzwyczajeń żywieniowych i aktywności fizycznej wśród dzieci szkolnych w wieku 6-13 lat w mieście Piekary śląskie. Pediatr Med. Rodz. 2015;11(3):302-314.

5. Tabak I, Oblacińska I, Jodłowska M. Psychospołeczne czynniki sprzyjające stosowaniu diety przez nastolatków z nadmia rem masy ciała. Med Og Nauk Zdr. 2014;20(2):120-125.

6. Szymocha M, Bryła M, Maniecka-Bryła I. Epidemia otyłości w XXI wieku. Zdr Publ. 2009;119(2):207-212.

7. Witek A, Lewandowska-Kidoń T, Pawluk-Skrzypek A. Percepcja otyłego rówieśnika a przekonania zdrowotne młodzieży gimnazjalnej. Med Og Nauk Zdr. 2012;18(4):276-280. 
8. Jarosz M, Wolnicka K, Kłosowska J. Czynniki środowiskowe związane z występowaniem nadwagi i otyłości wśród dzieci i młodzieży. Post Nauk Med. 2011;9:770-777.

9. Woźniak-Holecka J, Sobczyk K. Organizacja szkolnej edukacji zdrowotnej dotyczącej otyłości u dzieci. Med Środow. 2013;16(4):64-70.

10. Pieszko M, Gaca M, Małgorzewicz S. Edukacja żywieniowa rodziny w przypadku występowania otyłości. Pediatr Med Rodz. 2013:9(4):399-403.

11. Wojtyła A, Biliński P, Bojar I, Wojtyła C. Zaburzenia odżywiania u polskich gimnazjalistów. Probl Hig Epidemiol. 2011;92(2):343-350
Zaakceptowano do edycji: 20.08.19

Zaakceptowano do publikacji: 26.09.19

Adres do korespondencji:

Dariusz Góra

Uniwersytet Śląski

Wydział Nauk o Ziemi

ul. Będzińska 60

41-200 Sosnowiec 